\title{
Tobacco consumption among ninth-grade students in Chisinau, Moldova
}

\author{
Aculina Topadă ${ }^{1}$, Valentin Nădăşan ${ }^{1}$, Monica Tarcea², Zoltán Ábrám ${ }^{1}$
}

\begin{abstract}
INTRODUCTION The aim of this study was to evaluate the potential impact of the changes in the national legislation on tobacco consumption and the impact of the implementation of the National Tobacco Control Program on ninth-grade students in Chisinau, Moldova, during 2015 and 2018, as well as tobacco consumption behavior and exposure to pro- and anti-tobacco messages.

METHODS The study sample consisted of the ninth-grade students from 132 schools in Chisinau, Moldova. It included 20 randomly selected schools (3 gymnasiums and 17 high schools). Data were collected using a validated self-completed questionnaire, once in October-December $2015(\mathrm{n}=368)$ and repeated in February-April $2018(\mathrm{n}=819)$. The chi-squared test was applied to compare categorical variables between the 2015 and 2018 groups.

RESULTS The student participants had mean age of $14.8 \pm 0.49$ years $(2015)$ and $14.9 \pm 0.53$ years $(2018)$, and, by coincidence, both groups had $51.9 \%$ boys and $48.1 \%$ girls. However, despite the rather strict regulations on tobacco in Moldova, adolescents still report a significant increase in the prevalence of cigarette consumption in the last 30 days in the period from 2015 to 2018 . In this period, anti-smoking messages increased significantly and were seen by students in shopping malls, supermarkets ( $35.1 \%$ in 2015 and $60.0 \%$ in 2018 ), cinemas ( $11.7 \%$ in 2015 and $36.5 \%$ in 2018 ), magazines and newspapers (19.3\% in 2015 and $37.6 \%$ in 2018$)(\mathrm{p}<0.001)$.

CONCLUSIONS Tobacco consumption among ninth-grade pupils had increased between 2015 and 2018 in Chisinau, Moldova. Adolescents represent a critical subpopulation of smokers and tobacco control experts must concentrate their efforts to reduce their exposure to pro-smoking messages and increase their exposure to anti-smoking messages (via internet, sport events, etc.).
\end{abstract}

\author{
AFFILIATION \\ 1 Department of Hygiene, \\ George Emil Palade University \\ of Medicine, Pharmacy, \\ Science, and Technology of \\ Targu Mures, Targu Mures, \\ Romania \\ 2 Department of Community \\ Nutrition and Food Safety, \\ George Emil Palade University \\ of Medicine, Pharmacy, \\ Science, and Technology of \\ Targu Mures, Targu Mures, \\ Romania
}

\section{CORRESPONDENCE TO}

Valentin Nădășan. George Emil Palade University of Medicine, Pharmacy, Science, and Technology of Targu Mure, $38 \mathrm{Gh}$. Marinescu street, 540139 Targu Mures, Romania. E-mail: valentin. nadasan@umfst.ro

KEYWORDS smoking, adolescents, Moldova

Received: 23 June 2021 Revised: 23 August 2021 Accepted: 9 September 2021

\section{INTRODUCTION}

Tobacco consumption represents a significant public health problem in the Republic of Moldova and the World Health Organization (WHO) estimated that in 2010 approximately $23 \%$ (690200 people) of its population were smokers ${ }^{1}$. In 2009 , significant efforts to combat tobacco consumption by acceding to the World Health Organization Framework Convention on Tobacco Control were made, and in 2012 the first National Program on tobacco control for the years
2012-2016 was approved ${ }^{2}$. In September 2015, the first amendment to the law on tobacco products was approved $^{3}$.

In 2011, the prevalence rate of smoking in the adult population (18-69 years) was $25 \%$ with a slight decrease in 2013 to $23.3 \%$. The rate of smoking continued to decrease to $21 \%$ in 2014 but increased in 2017 to $25 \%$.

Recent studies have shown that the prevalence of tobacco smoking among adolescents aged 15 years 
is different among cities in Europe. The average prevalence rate of daily smoking was: $26.8 \%$ in Latina (Italy), $24.5 \%$ in Namur (Belgium), $16.8 \%$ in Tampere (Finland), $12.2 \%$ in Hannover (Germany), $12.4 \%$ in Amersfoort (Netherlands), and $19.7 \%$ in Coimbra (Portugal $)^{8}$. Other studies also demonstrated that the socioeconomic status of school and family influence the smoking behavior of adolescents. The prevalence of daily smoking was higher in schools with low socioeconomic status and among students from families where the parents had a low education level9.

The European School Survey Project on Alcohol and Other Drugs study (ESPAD) found the following lifetime smoking prevalence rates among adolescents aged 13 years from Europe: 66\% Czech Republic, 65\% Lithuania, 62\% Croatia and Slovakia, 58\% Romania, and 33\% Moldova. The highest prevalence rate of students who smoked cigarettes during the last 30 days was found in Italy (37\%), Romania (30\%), and Moldova (9\%). This study found the most significant gender differences in the lifetime use of cigarettes in Moldova ( $50 \%$ for boys vs $15 \%$ for girls $)^{10}$. In Europe, the ESPAD study ${ }^{11}$ in 2019 found on average that $20 \%$ of students had smoked cigarettes during the last 30 days and $41 \%$ of students ever smoked cigarettes. The same study reported the following prevalence rates among the students who smoked cigarettes during the last 30 days: $21 \%$ Spain, $22 \%$ Ukraine, and $31 \%$ Romania. According to the Leal-López study ${ }^{12}$, the daily smoking prevalence among Spanish adolescents aged $15-18$ years in 2018 was $8.7 \%$, and the prevalence among adolescents aged 15-16 years who smoked less than once a week was approximately $6 \%$.

The most recent survey, in Moldova in 2016 involving young people aged 14-29 years, revealed that the daily tobacco use prevalence was $16.5 \%$ and for occasional use $7.2 \%$. About $13.7 \%$ of young men aged 14-19 years smoked daily and $12.4 \%$ occasionally, while the prevalence rate among young women of the same age group was only $1.2 \%$ for daily and $1.7 \%$ for occasional smoking ${ }^{13}$. A study conducted among adolescents in Moldova in 2015 showed that about $30 \%$ of students in the 8 th and 9 th grades smoked at least once during their lifetime. This study included students from rural and urban areas, and showed that lifetime smoking prevalence among students in large urban centers was higher (38.5\%) compared to other places of residence $(30.2 \%$ urban; $27.9 \%$ rural $)^{14}$.

The study ${ }^{15}$ conducted in 2016 analyzed risky behaviors among adolescents in Moldova, and applying only a few questions about tobacco use found that $9.9 \%$ of students aged 15 years were current smokers in 2014.

The prevalence of tobacco consumption in Romania among the ninth-grade students was estimated at $48.4 \%$ for those who have tried to smoke at least once, and $21.4 \%$ for those who were current smokers ${ }^{16}$. Among resident children from foster-care homes in four Transylvanian counties, $44.6 \%$ had tried to smoke cigarettes at least once and about one in four $(25.9 \%)$ reported that they smoked cigarettes in the past 30 days ${ }^{17}$. Another study among institutionalized children in family-care homes in Romania found that $61 \%$ of the children from Harghita county and $54.3 \%$ from Mures county tried to smoke cigarettes ${ }^{18}$.

Assessment across the 27 European Union (EU) Member States showed that from 2006 to 2014, the prevalence rate of smoking had decreased in Europe. The higher implementation level of tobacco control policies is associated with a lower prevalence rate of smoking, but the decrease of the prevalence rate varies across the countries. In some countries, the prevalence rate has fallen by more than $40 \%$ (Sweden, Latvia) while in others it has fallen insignificantly or not at all, as in Bulgaria and France ${ }^{19}$.

The aim of the present study was to evaluate the impact of the national legislation on tobacco consumption and also of the National Tobacco Control Program upon the ninth-grade students in Chisinau, Moldova, during the period 2015-2018, as well as tobacco consumption behavior and exposure to proand anti-tobacco messages.

\section{METHODS}

\section{Sample and data collection}

The study sample consisted of 9th grade students from 132 schools located in Chisinau, the capital of the Republic of Moldova. It included 20 randomly selected schools ( 3 gymnasiums and 17 high schools). Data were collected using a self-completed questionnaire, once in October-December 2015 (368 respondents) and repeated in February-April 2018 (819 respondents). The inclusion criteria were schools: 1) having at least one ninth-grade class; 2) 
teaching in Romanian; 3) located in Chisinau, but not in the suburbs; 4) with no special sports or health profile; 5) with no evening classrooms (where students are older than 18 years); 6) which had an IT class; and 7) where it was possible to obtain the agreement of the school director to participate in the study. The list of eligible schools in the municipality was obtained from the General Directorate of Education, Youth and Sports (DGETS) of the Chisinau Municipal Council. After analyzing all the schools, 41 high schools and 7 gymnasiums qualified. The study sample was chosen randomly and consisted of 17 high schools and 3 gymnasiums, in total 20 pre-university educational institutions. The sample size was calculated using a $95 \%$ confidence level and an expected proportion of $50 \%$ from an estimated population size of 3500 pupils from 48 schools. Also, we doubled the number of subjects in order to adjust for the cluster effect.

The survey was conducted in two stages; during the first stage, implemented in the period OctoberDecember 2015, the questionnaire included 368 students; in the second stage, which was implemented in the period February-April 2018, the same educational institutions were included, except for one high school that did not have a ninth grade in the period 2017-2018.

The first group in 2015 completed the online questionnaire in the computer class. The second group in 2018 completed an onsite paper-andpen questionnaire. Fifteen classes from one school declined to participate due to organizational reasons. The remaining sample included 19 schools, 40 classes; therefore, out of 1531 students enrolled in the ninth grade, 819 students were interviewed. In 237 cases, the students refused to fill in the questionnaire; in 475 cases, their parents refused to accept their participation in the study or did not submit their written consent before completing the questionnaire.

The study obtained the approval of the Ethics Commission of Scientific Research of the University of Medicine, Pharmacy, Sciences and Technology of Targu Mures, Romania, where the ASPIRA program was implemented. Parents were informed of the purpose, benefits and risks of the research and gave their written consent before conducting the questionnaire. The written consent consisted of two parts: in the first was included general information about the questionnaire, explaining what the questionnaire consists of, by whom it is carried out and what data were required from the students; in the second they were required to enter personal data and confirm that they agreed with the use and processing of the personal data in the study, according to the national legislation in force.

The validated questionnaire applied in Chisinau was taken from the project 'The school Action Software to Prevent Interactive Smoking in Romania (ASPIRA)' implemented within the program Building Capacity for Tobacco Research in Romania: A Partnership among Romanian, American, and Hungarian Scientists. The questionnaire used for the study was that from the ASPIRA program applied in Targu Mureş, Romania, in $2016^{16}$. The questionnaire was structured in such a way as to collect general data about students, followed by data related to the smoking behavior of students and their family members. It included questions about the motivation to smoke or not, the temptation to smoke or the confidence to resist the temptation.

\section{Measurements}

Smoking status was assessed by collecting information about ever trying conventional cigarettes and past 30-day use of conventional cigarettes. The following sociodemographic data were collected: age, gender, and ethnicity. Social influences were measured by perceived household members' and peers' smoking status (smoking status of the father, mother, siblings, close friends). Two items measured the variables for exposure to pro- and anti-smoking messages: 'Please choose the types of pro-smoking messages that you have seen or heard in the last month' (yes/no) and 'Please choose the types of anti-smoking messages that you have seen or heard in the last month' (yes/ no). The questions investigating exposure to pro- and anti-smoking messages covered the most common sources such as radio, television, outdoor advertising, cinema, newspapers, internet, sports events, shops, and supermarkets. The variables are described in detail in Nădăşan et al. ${ }^{20}$.

\section{Statistical analysis}

Means and standard deviations were calculated for the age of the participants. Absolute and relative frequencies were calculated for all the categorical variables. Chi-squared test was applied to compare categorical variables from 2015 with those from 2018. 
The threshold for statistically significant differences was set at 0.05 .

\section{RESULTS}

Table 1 presents the sociodemographic variables of the investigated samples. The 2015 sample had a mean age of $14.8 \pm 0.49$ years, with a slightly higher average age of $14.9 \pm 0.53$ years in 2018 . The respondents were $51.9 \%$ boys and $48.1 \%$ girls, for both study groups.

Table 1. Sociodemographic characteristics of the ninth-grade students, Chisinau, Moldova, 2015 and 2018

\begin{tabular}{|c|c|c|c|}
\hline Characteristics & $\begin{array}{c}2015 \\
(n=368) \\
n(\%)\end{array}$ & $\begin{array}{c}2018 \\
(n=819) \\
n(\%)\end{array}$ & $p$ \\
\hline Age (years), mean \pm SD & $14.8 \pm 0.49$ & $14.9 \pm 0.53$ & $0.02^{*}$ \\
\hline \multicolumn{4}{|l|}{ Sex } \\
\hline Boys & 191 (51.9) & 425 (51.9) & \multirow{2}{*}{$0.998^{* *}$} \\
\hline Girls & $177(48.1)$ & $394(48.1)$ & \\
\hline \multicolumn{4}{|l|}{ Ethnicity } \\
\hline Moldovan (Romanian) & 353 (95.9) & 779 (95.1) & \multirow{4}{*}{$0.540^{* * *}$} \\
\hline Ukrainian & $3(0.8)$ & $4(0.5)$ & \\
\hline Russian & $5(1.4)$ & $20(2.4)$ & \\
\hline Other & $7(1.9)$ & $16(2.0)$ & \\
\hline
\end{tabular}

*Value of $p$ was calculated using the t-test. ${ }^{* *}$ Chi-squared test, two-tailed $p .{ }^{* *}$ Chisquared test compared the Moldovan ethnics with all the other ethnics combined.

Table 2. Smoking status of ninth-grade students, their parents, siblings and friends, Chisinau, Moldova, 2015 and 2018

\begin{tabular}{|c|c|c|c|}
\hline Variables & $\begin{array}{c}2015 \\
(n=368) \\
n(\%)\end{array}$ & $\begin{array}{c}2018 \\
(n=819) \\
n(\%)\end{array}$ & $p *$ \\
\hline \multicolumn{4}{|l|}{$\begin{array}{l}\text { Smoking status of } \\
\text { students }\end{array}$} \\
\hline Ever tried cigarettes & $166(45.1)$ & 457 (55.8) & 0.001 \\
\hline $\begin{array}{l}\text { Last } 30 \text { days cigarette } \\
\text { users }\end{array}$ & 55 (14.9) & $384(46.9)$ & $<0.0001$ \\
\hline \multicolumn{4}{|l|}{$\begin{array}{l}\text { Smoking status of } \\
\text { parents, siblings and } \\
\text { friends }\end{array}$} \\
\hline Father smoker & $103(28.0)$ & 261 (31.9) & 0.180 \\
\hline Mother smoker & $25(6.8)$ & $96(11.7)$ & 0.009 \\
\hline Brother/sister smoker & 49 (13.3) & 155 (18.9) & 0.017 \\
\hline Close friends smokers & $182(49.5)$ & 478 (58.4) & 0.004 \\
\hline
\end{tabular}

${ }^{*}$ Chi-squared test, two-tailed $\mathrm{p}$
Table 2 presents the characteristics of the smoking status of the respondents for 2015, and for 2018 which was used as a post-intervention group. Smoking prevalence and intensity were significantly higher in 2018; about $55.8 \%$ of students ever tried cigarettes, and $46.9 \%$ of students used cigarettes in the last 30 days. Having friends, parents or siblings who smoked was also more common in 2018.

Details about the exposure of the ninth-grade students to pro- and anti-smoking messages are presented in Table 3 . The study shows that the most effective and stable ways to reach students with antismoking messages is via radio/television and the internet. These sources have a rate of $>50 \%$ both until the implementation of the legislation requiring the publication of such messages and after its implementation. Approximately $60 \%$ of respondents accepted that they saw or heard advertisements with anti-smoking messages in commercial spaces in 2018 , compared to $35.1 \%$ of students in 2015 . The sources of exposure that increased due to the implementation

Table 3. Exposure of ninth-grade students to prosmoking and anti-smoking messages, Chisinau, Moldova, 2015 and 2018

\begin{tabular}{lcc|c}
\hline Source of exposure & $\begin{array}{c}2015 \\
(n=368)\end{array}$ & $\begin{array}{c}2018 \\
(n=819) \\
n(\%)\end{array}$ & \\
\hline Pro-smoking messages & $n(\%)$ & & \\
\hline Radio/television & $67(18.2)$ & $162(19.7)$ & 0.525 \\
Outdoor advertisement & $49(13.3)$ & $112(13.7)$ & 0.867 \\
Shopping areas & $37(10.1)$ & 10.1 & 0.966 \\
Cinema & $14(3.8)$ & $28(3.4)$ & 0.739 \\
Newspapers/magazines & $18(4.9)$ & $36(4.4)$ & 0.705 \\
Internet & $106(28.8)$ & $232(28.3)$ & 0.866 \\
Sport events & $24(6.5)$ & $53(6.5)$ & 0.974 \\
Other & $37(10.1)$ & $90(11.0)$ & 0.630 \\
Anti-smoking & & & \\
messages & & & \\
Radio/television & $204(55.4)$ & $489(59.7)$ & 0.167 \\
Outdoor advertisement & $180(48.9)$ & $393(48.0)$ & 0.767 \\
Shopping areas & $129(35.1)$ & $491(60.0)$ & $<0.001$ \\
Cinema & $43(11.7)$ & $299(36.5)$ & $<0.001$ \\
Newspapers/magazines & $71(19.3)$ & $308(37.6)$ & $<0.001$ \\
Internet & $207(56.3)$ & $464(56.7)$ & 0.897 \\
Sport events & $99(26.9)$ & $251(30.6)$ & 0.191 \\
Other & $80(21.7)$ & $187(22.8)$ & 0.676
\end{tabular}

${ }^{*}$ Chi-squared test, two-tailed $p$. 
of the legislation were: cinema from $11.7 \%$ (2015) to $36.5 \%$ (2018); and newspapers/magazines from $19.3 \%$ (2015) to $37.6 \%$ (2018). In contrast, the source of lowest exposure (26.9\%), which did not increase significantly (30.6\%) with the implementation of the legislation, were sports events.

Although Article 21 of the law which entered into force on 1 January 2018, which prohibits any form, direct or indirect, of advertising in favor of tobacco products, there has been no significant decrease in any of the sources of exposure to the messages of promotion of tobacco products. The most used source to which the students claimed to have been exposed was the internet in 2015 (28.8\%) and in 2018 $(28.3 \%)$. Just under $20 \%$ saw or heard pro-smoking messages through television and radio in both groups.

\section{DISCUSSION}

The public health problem related to adolescent smoking in Moldova is significant. However, the legislative changes and the implementation of European programs began much later than in some other European countries. A large part of the proposed measures entered into force gradually or remained not fully implemented. The political/economic situation of the Republic of Moldova and the signing of its Association Agreement with the European Union make it possible to implement new programs and action plans to reduce the prevalence rate of smoking among adolescents.

In this study were reported similar rates of current smoking compared with the general population of adolescents in Moldova in 2015 (13.7\% vs 14.9\%, respectively); in 2018 the current smoking was seven times higher than the prevalence reported in the GYTS ( $7.4 \%$ vs $46.9 \%$, respectively). These prevalence rates are comparable with previous research in Moldavian students $^{21-24}$. Ever trying cigarettes ( $45.1 \%$ in 2015 ) was also similar to previous findings for the GYTS ${ }^{21-24}$, while for the sample in 2018 , we found a markedly higher prevalence of $55.8 \%(\mathrm{p}<0.001)$.

Exposure to tobacco promotion is associated with the likelihood of teens starting to smoke ${ }^{25}$. Based on this association, we decided to study the level of implementation of tobacco control advertising in Moldova. Although, since 2003, the World Health Organization under Article 13 of the Framework Convention on Tobacco Control has laid down a comprehensive ban on tobacco advertising, promotion and sponsorship, Moldova only ratified this Article in 2015 . Until the ratification, some studies ${ }^{21-23}$ on adolescents in Moldova gave a proportion of $>45 \%$ of students who saw pro-smoking messages at a shopping area, and $>75 \%$ from radio/television. In our study, the exposure to the pro-smoking messages was 3 times lower than the studies conducted on Moldovan students ${ }^{21-23}$, especially those in the media and commercial spaces.

Exposure to the anti-smoking messages in our study had a significantly higher prevalence in 2018 than in 2015, especially the media exposure sources. Studies of adolescents have shown that anti-smoking media campaigns can help to reduce the prevalence of smoking by discouraging young people from starting smoking and by encouraging current smokers to quit $^{26}$.

The originality and timeliness of the study come through the comparison of data on tobacco use among students after the approval of the law on tobacco use in the Republic of Moldova. These surveys provide data on the correlation between the students' family and school and their influence on student behavior regarding smoking. Also, the study makes for the first time a comparison of the changes that appeared in the frequency of exposure to advertisements by the students at the beginning of the implementation of the law and after two years.

\section{Legislation implemented}

During the period 2015-2018, when the survey was conducted, in Moldova were approved and entered into force several amendments to the law on tobacco consumption. These amendments were proposed and approved as a result of Moldova's ratification of the WHO Framework Convention on Tobacco Control. The latest modification was adopted on 29 May 2015, and entered into force on 17 September 2015. The particularity of this law is that each amendment of the law enters into force on different dates. The most relevant amendment for our study was Article 21 on advertising and sponsorship of tobacco products by banning the advertising and promotion of tobacco products, which entered into force on 1 January $2016^{3}$.

Based on this law, the National Program on Tobacco Control for 2017-2021 was developed and 
implemented. The goal of the program was to improve population health through the reduction of tobacco consumption and the full implementation of the WHO Framework Convention on Tobacco Control ${ }^{27}$. Also in Moldova, other regulations on tobacco consumption entered into force, such as Government Decision No. 1065 of 19 September 2016 for the approval of the sanitary regulations regarding tobacco products and related products, and Government Decision No. 613 of 1 August 2017 for the approval of the sanitary regulation on health warnings and labeling of tobacco products, tobacco intended for the rolling of cigarettes and related products ${ }^{28,29}$.

The National Program on Tobacco Control for 2017-2021 and the Action Plan for its implementation imposed strict rules for the media, recommending to disseminate aggressive content with antismoking messages. The program also provides recommendations for the organization of information campaigns for promoting anti-smoking messages by the municipal councils of the town halls at the local level. Thus, several anti-smoking messages appeared in public spaces, supermarkets, and cinemas ${ }^{27,28}$.

The Inspectorate of the National Agency for Public Health was responsible for the monitoring the implementation of the law on prohibition of prosmoking messages; taking into consideration that the Agency was reorganized in 2017-2018, the control of the implementation of the law was partially ensured. The lack of control by the relevant body most likely led to the maintenance of the prevalence rate of exposure to flagrant messages among students who participated in the survey in $2018^{30}$.

\section{Limitations}

Limitations of the study include the lack of a sufficient number of computers in the computer classes that limited the possibility to involve a greater number of students in the survey in 2015. For the ICT lessons, the classes are divided usually into at least two groups.

\section{CONCLUSIONS}

A general increasing trend in cigarette use was observed among students from Chisinau during 2015-2018. However, despite rather strict regulations on tobacco use in Moldova, adolescents still reported a significant increase in the prevalence rate of cigarette consumption in the past 30 days. Fortunately, the frequency of anti-smoking messages has significantly increased and has been seen and read by students in shopping malls, supermarkets, cinemas, magazines, and newspapers. We highlight the importance of community preventive interventions in Moldovan schools, sustained by targeted laws, in order to reduce the frequency of smoking and associated chronic diseases.

\section{REFERENCES}

1. World Health Organization. WHO global report on trends in prevalence of tobacco smoking. World Health Organization; 2015. Accessed April 15, 2021. https://apps.who.int/iris/ bitstream/handle/10665/156262/9789241564922_eng. pdf? sequence $=1$

2. Republica Moldova. Government Decision no. 100 of 1602-2012 regarding the approval of the National Program on tobacco control for the years 2012-2016. Hotărârea Guvernului Republicii Moldova nr.100 din 16.02.2012 cu privire la aprobarea Programului naţional privind controlul tutunului pentru anii 2012-2016. Accessed April 16, 2021. https://www.legis.md/cautare/getResults?doc_ id=19917\& \&lang=ro

3. Republic of Moldova - Ministry of Justice. Law of the Republic of Moldova no. 278 of 14.12.2007 on tobacco and tobacco products modification on 17.09.2015. Legea Republicii Moldova nr. 278 din 14.12.2007 privind controlul tutunului şi produselor din tutun, modificare la 17.09.2015. Accessed May 08, 2021. http://lex.justice.md/ index.php?action $=$ view\&view $=$ doc\&lang $=1 \&$ id $=360910$

4. WHO Regional Office for Europe. Prevalence of noncommunicable disease risk factors in the Republic of Moldova: STEPS 2013. WHO Regional Office for Europe; 2014. Accessed May 15, 2021. https://www. euro.who.int/__data/assets/pdf_file/0009/252774/ PREVALENCE-OF-NONCOMMUNICABLE-DISEASERISK-FACTORS-IN-THE-REPUBLIC-OF-MOLDOVASTEPS-2013.pdf

5. WHO Regional Office for Europe. Health systems respond to noncommunicable diseases: time for ambition. Jakab M, Farrington J, Borgermans L, Mantingh F, eds. World Health Organization; 2018. Accessed May 15, 2021. http://www.euro.who.int/__data/assets/pdf_ file/0009/380997/Book-NCD-HS.pdf

6. Magenta Consulting. Kap Study. Baseline Survey NationWide Communication Campaign Targeting Current and Potential Tobacco Users. 2012. Accessed September 17, 2021. https://consulting.md/pic/uploaded/Rapoarte/ Magenta\%20Consulting\%20\%20Report $\% 20 \% 20 \mathrm{KAP} \% 20$ $\% 20$ Anti-smoking $\% 20$ Baseline $\% 20$ Survey_ENG_ Formatted.pdf

7. WHO Regional Office for Europe. KAP Survey. Knowledge, Attitudes and Practices Regarding Tobacco Consumption Phase I-IV. World Health Organization; 
2018. Accessed May 15, 2021. https://msmps.gov.md/ sites/default/files/kap_study_2017_tobacco_control_ en.pdf

8. Lorant V, Soto VE, Alves J, et al. Smoking in schoolaged adolescents: design of a social network survey in six European countries. BMC Res. Notes. 2015;8:91. doi:10.1186/s13104-015-1041-z

9. Leão T, Kunst AE, Schreuders M, Lindfors P, Kuipers MA, Perelman J; SILNE-R Group. Adolescents' smoking environment under weak tobacco control: A mixed methods study for Portugal. Drug Alcohol Depend. 2019;204:107566. doi:10.1016/j.drugalcdep.2019.107566

10. Kraus L, Guttormsson U, Leifman H, et al. ESPAD Report 2015: Results from the European School Survey Project on Alcohol and Other Drugs. European Monitoring Centre on Drugs and Drug Addiction, European School Survey Project on Alcohol and Other Drugs; 2016: 104. doi: $10.2810 / 564360$

11. The ESPAD Group. ESPAD Report 2019: Results from the European School Survey Project on Alcohol and Other Drugs. European Monitoring Centre for Drugs and Drug Addiction, European School Survey Project on Alcohol and Other Drugs; 2020. Accessed April 29, 2021. http:// www.espad.org/sites/espad.org/files/2020.3878_EN_04. pdf

12. Leal-López E, Sánchez-Queija I, Moreno C. Trends in tobacco use among adolescents in Spain (2002-2018). Adicciones. 2019;31(4):289-297. doi:10.20882/adicciones.1111

13. Crîşmaru M. Social patterns of smoking and alcohol drinking among young people in Moldova. Economy and Sociology. 2019;1:133-144. doi:10.36004/nier.es.2019.1-11

14. Ministry of Health - Republic of Moldova - National Center of Health Management, European Monitoring Centre for Drugs and Drug Addiction. Alcohol, drugs and tobacco use among students in 8th and 9th grades, Republic of Moldova, 2015. Accessed May 10, 2021. https://www. emcdda.europa.eu/system/files/attachments/12008/ ENP-ESPAD-final-report_Moldova-2015.pdf

15. Republic of Moldova - Health Behavior in Schoolaged Children. Behavioral and Social Determinants of Adolescent Health. Health Behavior in School-aged Children; 2015. Accessed April 11, 2021. https:// www.undp.org/content/dam/unct/moldova/docs/pub/ HBSC\%20report\%20Moldova\%20en.pdf

16. Nădăşan V, Foley KL, Pénzes M, et al. The Short-term Effects of ASPIRA: A Web-based, Multimedia Smoking Prevention Program for Adolescents in Romania: A Cluster Randomized Trial. Nicotine Tob Res. 2017;19(8):908915. doi:10.1093/ntr/ntw308

17. Lorand FI, Zoltan A, Lorand S, Peter B, Foley KL. Tobacco use among children in Romanian foster care homes. Eur J Public Health. 2016;26(5):822-826. doi:10.1093/eurpub/ckw044

18. Ferencz L, Finta H, Schmidt L, Balint I, Nadasan V,
Abram Z. Smoking habits of children institutionalized in family care homes in Mures and Harghita county. Acta Med Marisiensis. 2015;61(3):209-212. doi:10.1515/amma-2015-0042

19. Feliu A, Filippidis FT, Joossens L, et al. Impact of tobacco control policies on smoking prevalence and quit ratios in 27 European Union countries from 2006 to 2014. Tob Control. 2019;28(1):101-109. doi:10.1136/tobaccocontrol-2017-054119

20. Nădăşan V, Foley KL, Pénzes M, et al. Use of electronic cigarettes and alternative tobacco products among Romanian adolescents. Int J Public Health. 2016;61(2):199-207. doi:10.1007/s00038-015-0774-8

21. World Health Organization. Global Youth Tobacco Survey 2004. Accessed April 8, 2021. https://extranet.who.int/ ncdsmicrodata/index.php/catalog/564

22. World Health Organization. The Global Youth Tobacco Survey 2008: Republic of Moldova, 2008. Accessed April 8, 2021. https://extranet.who.int/ncdsmicrodata/index. $\mathrm{php} / \mathrm{catalog} / 566$

23. World Health Organization. Global Youth Tobacco Survey 2013: Republic of Moldova, 2013. Accessed April 8, 2021. https://extranet.who.int/ncdsmicrodata/index.php/ catalog/567

24. Arrazola RA, Seidenberg AB, Ahluwalia IB. Percentage of current tobacco smoking students receiving help or advice to quit: Evidence from the Global Youth Tobacco Survey, 56 countries, 2012-2015. Tob Prev Cessat. 2019;5(January). doi:10.18332/tpc/102994

25. Lovato C, Watts A, Stead LF. Impact of tobacco advertising and promotion on increasing adolescent smoking behaviours. Cochrane Database Syst Rev. 2011:CD003439. doi:10.1002/14651858.CD003439.pub2

26. Chauhan A, Sharma R. Impact of Anti Smoking Campaigns on Youth. Procedia Comput Sci. 2017;122:941-948. doi:10.1016/j.procs.2017.11.458

27. Republic of Moldova - Ministry of Justice. Decision no. 1015 of November 23, 2017 approves the National Program on tobacco control for the years 2017-2021. AHOTĂRÎRE Nr. 1015 din 23-11-2017 cu privire la aprobarea Programului național privind controlul tutunului pentru anii 2017-2021 şi a Planului de acțiuni pentru implementarea acestuiaccessed. Accessed May 10, 2021. https://www.legis.md/cautare/getResults?doc_ id $=110638 \&$ lang $=$ ro

28. Republic of Moldova - Ministry of Justice. Decision no. 1065 of 19-09-2016 for the approval of the sanitary regulations regarding tobacco products and related products. Hotărârea Guvernului Republicii Moldova nr. 1065 din 19.19.2016 pentru aprobarea regulamentelor sanitare privind produsele din tutun şi produsele conexe, ultima modificare 20.05.2020. Accessed May 2021. https://www.legis.md/cautare/getResults?doc_ $\mathrm{id}=121483 \&$ \&lang $=$ ro

29. Republic of Moldova - Ministry of Justice. Government 
Decision no. 613 of 01-08-2017 for the approval of the sanitary regulation on health warnings and labeling of tobacco products, tobacco intended for the rolling of cigarettes and related products. Hotărârea Guvernului Republicii Moldova nr.613 din 01.08.2017 pentru aprobarea Regulamentului sanitar privind avertismentele de sănătate și etichetarea produselor din tutun, a tutunului destinat rulării în țigarete şi a produselor conexe, a intrat în vigoare la 01.01.2018. Accessed May 15, 2021. https://www.legis.md/cautare/getResults?lang=ro\&doc_ id $=101387$

30. Republic of Moldova - Ministry of Justice. Law of the Republic of Moldova no. 10 of 03.02.2009 on state surveillance of public health, version in force since 18.12.17. Lege nr.10 din 03.02.2009 privind supravegherea de stat a sănătăţii publice, modificat la 18.12.2017. Accessed April 23, 2021. https://www.legis. $\mathrm{md} /$ cautare/getResults?doc_id=106568\&lang=ro\#
CONFLICTS OF INTEREST

The authors have completed and submitted the ICMJE Form for Disclosure of Potential Conflicts of Interest and none was reported.

\section{FUNDING}

There was no source of funding for this research.

\section{ETHICAL APPROVAL AND INFORMED CONSENT}

The study obtained the approval of the Ethics Commission of Scientific Research of the University of Medicine, Pharmacy, Sciences and Technology of Targu Mures, Romania, where the ASPIRA program was implemented (Decision No. 19/20.05.2013 and 42/23.02.2018). Parents were informed of the purpose, benefits and risks of the research and gave their written consent before conducting the questionnaire.

\section{DATA AVAILABILITY}

The data supporting this research are available from the authors on reasonable request.

\section{AUTHORS' CONTRIBUTIONS}

ZÁ coordinated and planned the study. VN designed, carried out the statistical analysis and data interpretation. MT was in charge of the English translation and references citations. AT performed the implementation of the study, drafted and wrote the final version of the manuscript. All authors were involved in the critical review of the manuscript and have approved the final version for publication.

PROVENANCE AND PEER REVIEW

Not commissioned; externally peer reviewed. 